\title{
Efficacy and safety of low molecular weight heparin compared to unfractionated heparin for chronic outpatient hemodialysis in end stage renal disease: systematic review and meta- analysis
}

Ghanshyam Palamaner Subash Shantha, Anita A. Kumar, Mansha Sethi, Rohit C. Khanna, Samir B Pancholy

Background: Low molecular weight heparin (LMWH) is an effective anti-coagulant for thrombotic events. However, due to its predominant renal clearance, there are concerns that it might be associated with increased bleeding in patients with renal disease.

Objectives: We systematically evaluated the efficacy and safety of LMWH compared to unfractionated heparin (UH) in end stage renal disease (ESRD) patients.Search methods:

Pubmed, Embase and cochrane central were searched for eligible citations.Selection criteria: Randomized controlled trials, comparing LMWH and UH, involving adult (age $>18$ years), ESRD patients receiving outpatient, chronic, intermittent hemodialysis were included.Data collection and analysis: Two independent reviewers performed independent data abstraction. 12 statistic was used to assess heterogeneity. Random effects model was used for meta-analysis. Results: Nineteen studies were included for systematic review and 4 were included for meta-analysis. There were no significant differences between LMWH and UFH for extracorporeal circuit thrombosis [risk ratio: 1 (95\% C.I: 0.62 - 1.62)] and bleeding complications [risk ratio: 1.16 (95\% C.I: $0.62-2.15)$ ].Conclusions: LMWH is as safe and effective as UFH. Considering the poor quality of studies included for the review, larger well conducted RCTs are required before conclusions can be drawn. 


\section{Title page}

3 Title: Efficacy and Safety of Low Molecular Weight Heparin compared to Unfractionated Heparin for

4 Chronic Outpatient Hemodialysis in End Stage Renal Disease: systematic review and meta-analysis.

5 Short title: Heparin and Hemodialysis

6 Authors: Ghanshyam Palamaner Subash Shantha MD, $\mathrm{MPH}^{1,2}$, Anita Ashok Kumar MD, MPH ${ }^{1,2}$,

7 Mansha Sethi², Rohit C. Khanna MD, $\mathrm{MPH}^{3}$, Samir Bipin Pancholy MD, FACC, FSCAI ${ }^{4}$.

\section{Affiliations:}

9 1) The Wright Center for Graduate Medical Education, Scranton, PA, USA.

10 2) The Johns Hopkins University, Bloomberg School of Public Health, Baltimore, MD, USA.

113 3) Temple University School of Medicine, Philadelphia, PA, USA.

12 4) Allen Foster Research Centre for Community Eye Health, International Centre for Advancement 13 of Rural Eye care, L V Prasad Eye Institute, Hyderabad, India.

14 5) Department of Medicine, The Commonwealth Medical College, 501 Madison Avenue, Scranton, 15 PA: 18510, Scranton, Pennsylvania, USA

\section{Corresponding author:}

17 Dr. Ghanshyam Palamaner Subash Shantha MD, MPH

18 The Wright Center for Graduate Medical Education,

19 Scranton, PA: 18505, USA, Phone: 5706877643, Fax: 4432059580, Email:

20 shanthag@,thewrightcenter.org

\section{Abstract}


22 Background: Low molecular weight heparin (LMWH) is an effective anti-coagulant to prevent

23 thrombotic events. However, due to its predominant renal clearance, there are concerns that it might be 24 associated with increased bleeding in patients with renal disease.

25 Objectives: We systematically evaluated the efficacy and safety of LMWH compared to

26 unfractionated heparin (UH) in patients with end stage renal disease (ESRD).

27 Search methods: Pubmed, Embase and cochrane central were searched for eligible citations.

28 Selection criteria: Randomized controlled trials, comparing LMWH and UH, involving adult (age > 18

29 years), ESRD patients receiving outpatient, chronic, intermittent hemodialysis were included.

30 Data collection and analysis: Two independent reviewers performed independent data abstraction. $\mathrm{I}^{2}$

31 statistic was used to assess heterogeneity. Random effects model was used for meta-analysis.

32 Results: Nineteen studies were included for systematic review and 4 were included for meta-analysis.

33 There were no significant differences between LMWH and UH for extracorporeal circuit thrombosis

34 [risk ratio: 1 (95\% C.I: 0.62 - 1.62)] and bleeding complications [risk ratio: 1.16 (95\% C.I: 0.62 -

35 2.15)].

36 Conclusions: LMWH is as safe and effective as UH. Considering the poor quality of studies included 37 in the review, larger well conducted randomized controlled trials (RCTs) are required before 38 conclusions can be drawn.

41 Introduction: Chronic kidney disease (CKD) was prevalent in 25.8 million adults in the United States 42 in 2004 [1]. CKD prevalence will increase by 5 million every decade in the United States [2]. This 43 alarming increase in CKD prevalence is due to an associated increase in the prevalence of 
44 hypertension, type 2 diabetes mellitus and obesity in the United States [2, 3, 4]. CKD, obesity, 45 hypertension and diabetes in unison are estimated to cost the American health care system a sum of $46 \$ 110$ billion annually $[5,6]$. Heparin acts by accelerating the inhibition of thrombin, and also factors (F) Xa, IXa, XIa and 48 XIIa. Low molecular weight heparins (LMWH) are recently identified, widely used, heparin derivatives with a mean molecular weight of less than 8000 Daltons [7]. Commonly used LMWH are Bemiparin, Certoparin, Dalteparin, Enoxaparin, Nadroparin, Parnaparin, Reviparin and Tinzaparin [8]. They have a lower incidence of heparin induced thrombocytopenia [8,9, 10] compared to UH [8]. LMWHs, due to the shorter polysaccharide chain show a more pronounced FXa inhibitory profile, have a longer half-life and aids in once a day administration. However, action of LMWH depends on the length of the polysaccharide chain and hence, all LMWHs do not show the same inhibitory profile.

Observational studies showed that use of LMWH for prevention of extra-corporeal circuit thrombosis during dialysis sessions and graft or fistula thrombosis post dialysis in end stage renal disease (ESRD) patients were associated with greater bleeding risk compared to UH [11, 12]. RCTs that assessed efficacy of LMWH had either excluded patients with renal disease or through inadequately powered sub-group analysis, had shown that patients with renal disease may be at risk for increased bleeding events [13]. A systematic review and meta-analysis on the same topic was conducted by Lim et al. [14] in 2004 where they had abstracted data from 17 trials. They concluded that LMWH was as effective and safe as UH in patients with ESRD receiving regular hemodialysis [14]. However, as the authors had reported, risk of bias was high for the studies included in their metaanalysis and they were small population studies. 
67 globe use only these 2 drugs and not citrate as analyzed in the review by Lim et al [14], 2) we have

68 focused our review to only those LMWH that are currently approved by the Food and Drug

69 Administration (FDA). Hence, our review will be clinically relevant for US dialysis centers, 3) we

70 have only included studies that had an explicit random allocation. We excluded controlled clinical

71 trials that did not have an explicit random allocation; the review by Lim et. al. [14] had included

72 controlled trials that did not have an explicit random allocation. Hence, it is likely that our estimates

73 are less biased. Hence via this systematic review and meta-analysis we have compared the efficacy and

74 safety of LMWH compared to UH in patients with ESRD receiving outpatient, chronic, intermittent

75 hemodialysis for dialysis associated events (examples: extra-corporeal circuit thrombosis graft/fistula

76 thrombosis and bleeding complications). This review does not attempt to compare the 2 types of

77 heparins for treatment of deep vein thrombosis or pulmonary embolism in these patients.

78 Methods: The protocol of this study can be found as a supplemental file. This protocol was approved

79 by the Johns Hopkins Centers for Clinical Trials, Baltimore, Maryland, USA.

80 Data sources: We searched 3 databases namely: 1) Pubmed, 2) Embase, 3) Cochrane central. We did

81 not use language or date restrictions when we searched for citations. Detailed search strategy has been

82 explained in the appendix. A librarian from Johns Hopkins University Bloomberg School of Public

83 Health, Baltimore, Maryland, USA helped us develop the search strategy. Date of last search was 24th

84 November 2014.

85 Study selection: Criteria for study inclusion in this review were: 1) RCTs comparing LMWH and UF;

we only included studies where the intervention allocation was truly random. Quasi-randomized or any other types of non-random intervention allocation were criteria for exclusion. 2) We included any RCT that used LMWH approved by the FDA; this included Dalteparin, Enoxaparin, and Tinzaparin. 3) The study participants in the included studies were adult patients (age $>18$ years) with end stage renal 
90 disease (ESRD), 4) The study participants were receiving chronic, intermittent, out-patient

91 hemodialysis for renal replacement therapy. Only human studies were included. We excluded studies

92 where LMWH was administered to patients not for the indication of anti-coagulation for hemodialysis

93 but for therapy of another condition such as deep vein thrombosis, pulmonary embolism etc. Three

94 reviewers independently assessed studies for eligibility. After title and abstract review, full texts of

95 those citations determined eligible were assessed. From these full text citations, those that satisfied all

96 criteria for inclusion were included in the review. Discrepancy was resolved by consensus.

97 Outcomes of our review: We focused on clinically relevant outcomes as primary outcomes for this

98 review. They were: 1) extracorporeal circuit thrombosis during dialysis session: abstracted as presence

99 or absence (yes/no), 2) graft or fistula thrombosis 7 days after trial drug administration (abstracted as

$100 \mathrm{yes} / \mathrm{no}$ ); rationale being that we expected to remove confounding due to other factors that might play a

101 role in graft and fistula thrombosis and hence 7 days would have been adequate time for the same.

102 Other secondary outcomes considered are: 1) bleeding complications (i.e. intra-cranial hemorrhage,

103 hemorrhagic stroke or any clinically recorded bleeding) - abstracted as number of patients with events,

104 2) Deep vein thrombosis (DVT) - abstracted as number of patients with events, 3) Pulmonary

105 embolism (PE) (abstracted as number of patients with events), 4) Vascular compression time

106 (abstracted as continuous variable in seconds), 5) Lipid Profile: [low density lipoprotein (LDL), high

107 density lipoprotein (HDL), very low density lipoprotein (VLDL), Total Cholesterol, LDL/HDL ratio)] -

108 (abstracted as continuous variables).

109 Other data abstracted from included studies: type of RCT (including: year(s) of conduct, total

110 sample size, study duration, date study commenced, place or region of study), study methodology

111 (including eligibility criteria, methods of randomization, type of randomization sequence followed,

112 allocation sequence concealment, and masking, washout period), participant characteristics: total 
113 number, setting (hospital based or free-standing), age, sex, country, race, comorbidities (diabetes,

114 hypertension, bleeding disorders, autoimmune disorders), frequency of dialysis, intervention: LMWH

115 and UH (dose, name of drug, route of drug, timing relative to hemodialysis, frequency of

116 administration).

117 Assessment of risk of bias in included studies: Risk of bias was assessed by two independent

118 reviewers. When there was a discrepancy, it was resolved by consensus. The studies were evaluated for

119 the following criteria: 1) allocation, 2) masking of investigators and participants, 3) masking of

120 outcome assessment, 4) loss to follow-up (attrition) and intention to treat analysis. Details of risk of

121 bias assessment are mentioned in the protocol in the supplemental files.

122 Statistical analysis: We followed the analysis plan outlined in the protocol. We reported relative risks

123 and $95 \%$ confidence intervals of the relative risks for all dichotomous outcomes. For continuous

124 outcomes we calculated means, mean difference and standard deviations. Clinical heterogeneity was

125 determined based on clinical knowledge. Methodological heterogeneity was assessed based on run in

126 period, duration of study, adequacy of randomization etc. Statistical heterogeneity was assessed using

$127 \mathrm{I}^{2} . \mathrm{I}^{2}$ of $25 \%, 50 \%$ and $75 \%$ was considered low, moderate and high heterogeneity respectively. If there

128 were more than 10 included studies in the meta-analysis we had apriori decided to use funnel plots to

129 assess reporting bias. Since our meta-analysis included only 4 studies we did not perform a funnel plot.

130 Studies were pooled with the random effects model as we suspected significant heterogeneity;clinical,

131 and methodological in the studies to be included in the meta-analysis. $\mathrm{P}<0.05$ was considered

132 statistically significant. Though apriori we had planned to do a sub-group analysis based on different

133 types of LMWHs, due to small number of included studies for meta-analysis, we were unable to

134 conduct sub-group analysis as planned. Though apriori we did plan to perform sensitivity analysis 
135 based on study quality, since all included studies were similarly of poor quality we could not perform

136 this sensitivity analysis.

137 Results: In total we had 4095 citations retrieved after searching the three databases. After removing 138 duplicates we were left with a final list of 3735 citations. Of these, 19 citations were included in the 139 review and 4 were pooled in the meta-analysis. Please refer to Figure 1 for the study flow details.

140 Characteristics of included studies (Table 1): Among the 19 included RCTs [15 - 33], 6 had a 141 parallel group design and 13 had a cross-over design. Most regions of the world were represented, with 1425 studies from Poland, 2 studies each from Netherland, Germany and United Kingdom and 1 study 143 each from United States, Greece, France, Canada, Sweden, Turkey, Australia and Romania. Seven 144 studies had evaluated enoxaparin, 6 dalteparin, and 5 evaluated tinzaparin. Sample size ranged from 8 145 to 70 participants. None of the studies explicitly defined a run-in period. 13 of the 19 studies had used a 146 fixed LMWH dose and the remaining used a variable dose of LMWH. The fixed dose was usually 147 between $0.69 \mathrm{mg} / \mathrm{kg}-1 \mathrm{mg} / \mathrm{kg}$. For UH, most studies had used a bolus dose initially and was followed 148 by an infusion. Thirteen studies had used a fixed dose of UH and 6 used variable dose of UH. The 149 fixed dose comprised of 1500 - 5000 IU bolus followed by 36 - $62 \mathrm{IU} / \mathrm{Kg}$ infusion.

150 Patient characteristics (Table 2): All study patients were adults (age $>18$ years) with ESRD. Age 151 ranged between 27 - 43 years. None of the study participants in any of the included studies had hyper152 coagulable conditions or were receiving anti-coagulant or anti-platelet drugs. Diabetic nephropathy 153 was the commonest in both these studies (33 - 36\%) followed by hypertensive nephropathy $(27 \%)$ and 154 then by lupus nephritis (19\%). All received regular, maintenance, outpatient hemodialysis. The dialysis 155 frequency ranged between 3 - 5 sessions every week. Duration of dialysis was 4 - 5 hours. Loss to 156 follow-up ranged between $10-17 \%$ in the reported studies. Details of patient characteristics can be 
157 seen in tables 1 and 2. Comorbid conditions of study participants are detailed in Supplemental Table 1.

158 The LMWH group and the UH group were similar with regards to the comorbid variables; diabetes

159 prevalence, hypertension prevalence, coronary artery disease prevalence, smoking prevalence, obesity

160 prevalence and dyslipidemia prevalence in most of the included studies (Supplemental Table 1)

161 Risk of bias in included studies: Please refer to Supplemental Figure 1 and Supplemental Table 2

162 for details of risk of bias assessment. In summary all included studies in the review were considered to

163 be of poor quality based on risk of bias assessment.

164 Study outcomes: Primary outcomes: none of the included studies assessed graft or fistula thrombosis.

165 Six studies had reported extracorporeal circuit thrombosis. Of which the study by Verzan 2004, though

166 had mentioned that the LMWH group and UH group were similar with regards to the number of people

167 with this outcome but did not report the exact numbers. Harenberg 1995 reported that LMWH group

168 (tinzaparin) did not differ with UH group as both groups had similar number of events (1/10 each). The

169 remaining 4 studies Borm 1986; Schrader 1988; Saltissi 1999; Lord 2002, had reported this outcome

170 for the total number of dialysis sessions in each group. The number of extracorporeal circuit

171 thrombosis/number of dialysis sessions encountered for the LMWH group in these 4 studies were

172 respectively $4 / 10,80 / 5045,17 / 1111$ and $32 / 378$ compared to $4 / 10,69 / 5197,35 / 1141,21 / 382$ in the UH

173 group. The risk ratio comparing LMWH to UH in these 4 studies were $1.00(0.34-2.93), 1.19$ [0.87,

$1741.64], 0.50[0.28,0.89]$, and $1.54[0.90,2.62]$ respectively (Table 3). The pooled risk ratio was 1.00

175 with a 95\% CI: 0.62 - 1.62. (Figure 2).

176 Secondary outcomes: Of the secondary outcomes, deep vein thrombosis and pulmonary embolism

177 were not reported by any of the included studies. Two studies (Lord 2002, Saltissi 1999) had addressed

178 vascular compression times. The vascular compression times for LMWH (Tinzaparin) (9.5 $\pm 3.0 \mathrm{~min})$ 
179 compared to UH (9.5 $\mathrm{min} \pm 1.8 \mathrm{~min})$ were similar in the study by Lord 2002. In Saltissi 1999, vascular

180 compression time for LMWH (enoxaparin) (388 \pm 164 seconds) was similar to that for UH (331 \pm 135

181 seconds). In total there were 5 studies that had addressed one or more of the lipid profile components.

182 The study by Mahmood 2010 had reported acute changes in triglyceride levels during dialysis with

183 LMWH (Tinzaparin) compared with UH. However, Saltissi 1999, reported lipid changes at 12 weeks

184 and observed that there were no differences in the lipid changes from baseline when LMWH

185 (enoxaparin) was compared to UH for LDL, HDL, total cholesterol, VLDL and triglycerides. However,

186 Schrader 1988 reported that UF group had significantly higher triglyceride and VLDL cholesterol

187 levels compared to UH group (Fragmin) $(\mathrm{P}<0.05)$ at the end of 12 months but the groups were similar

188 with LDL and HDL levels. Gritters 2006 observed that there were no differences between the LMWH

189 group and the UH group with regards to LDL levels measured at 1 week after study initiation. Elisaf

190 1997, showed that total cholesterol, triglycerides, LDL cholesterol and total cholesterol/HDL ratio

191 significantly decreased after LMWH (Tinzaparin) switch from UH at 3 months, 6 months and 12

192 months but HDL cholesterol did not significantly change during this period. Four studies had reported

193 bleeding complications (Borm 1986, Schrader 1988, Lord 2002 and Saltissi 1999). The number of

194 events/patient in each group were respectively 2/10,3/32, 12/36, and 19/35 for the LMWH group and

$1951 / 10,8 / 32,6 / 36$ and 16/35 for the UFH group. The risk ratio for bleeding in the LMWH group for

196 Borm 1986, Schrader 1988, Saltissi 1999 and Lord 2002 compared to UFH were respectively 2.00

197 (0.21 - 18.69), $0.38(0.11-1.29), 2.00(0.84-4.75)$ and $1.19(0.74-1.90)$ (Table 4). The pooled risk

198 ratio from meta-analysis of these 4 studies was $1.16(0.62-2.15)$ (Figure 3).

199 Discussion: In this systematic review and meta-analysis we observed that LMWH was similar to UH

200 with regards to extra-corporeal circuit thrombosis and bleeding complications. We did not find studies 
201 that assessed graft/fistula thrombosis and prevention of deep vein thrombosis and prevention of 202 pulmonary embolism

203 To the best of our knowledge only 1 other review by Lim et al. [14] has been published in this similar 204 topic. The important differences with that review are: 1) they had used LMWH that was approved in 205 Canada and we had used LMWH approved in the United States. Hence, 5 trials that had used 206 Nadroparin (LMWH approved in Canada but not in the US) were not included in our review [34, 35, $20736,37,38], 2)$ they had used studies that had citrate and other anti-coagulants as control group 208 whereas; we preferred to use only UH as control. Hence, 3 more trials that they had used were not in 209 our review for this reason [39, 40, 41, 42, 43], 3) They had used factor Xa levels as one of the 210 outcomes that denoted adequacy of action of $\mathrm{LMWH}$, but with the current available evidence, factor

211 Xa levels have been found not useful in clinical monitoring of LMWH efficacy and hence we opted not 212 to use this outcome for our analysis [44]. However, similar to their review, we found that LMWH was 213 similar to UH with respect to efficacy (extracorporeal circuit thrombosis) and safety (bleeding 214 complications) with LMWH approved for use in the US. However, since their review had larger 215 number of studies included for meta-analysis, their sample size was larger and hence, estimates were 216 more precise than ours. Only the study by Saltissi et al. showed LMWH to be strongly protective for 217 extracorporeal thrombosis, while our pooled estimate and that by the review by Lim et al. showed null 218 association. The reason for this observation is unclear. There was no obvious difference between this 219 study and the other studies. It might just mean there was a sampling variability in this study as 220 adequacy of dialysis and severity of uremia was not reported in this study. Also, among the LMWHs, 221 Tinzaparin is preferred in ESRD patients considering its higher molecular weight and lesser 222 dependence on renal functions for elimination from the body. However, due to small number of studies 
223 included in the meta-analysis, a subgroup analysis assessing individual LMWHs was not possible.

224 Hence, more RCTs are needed to assess comparative efficacy of one LMWH over the other.

225 Though we searched three large databases for this review, 5 non-English citations were excluded also,

22625 citations were un-retrieved so far. Further, we only included trials that had explicitly mentioned

227 random allocation. It is possible that some trials, though random allocation was not mentioned, may

228 have actually randomized their participants. Hence, due to all these factors it is possible that our final

229 included citations may not be all inclusive. However, since this is possibly random and does not have a

230 systematic component to it, it can tilt the effect estimate more towards null. Hence, more extensive

231 search is needed before we draw conclusions from the study.

232 Small sample size was an important limitation of our included trials. Not only does it reduce the

233 precision of our estimates, it creates doubts if the randomization was indeed adequate. Some included

234 studies had just 8 to 12 patients and it is possible that randomization did not work properly and hence

235 some confounding still remained. Further, blinding of outcome determination was unclear and attrition

236 was largely unreported in most trials. Also, there was significant clinical, statistical and methodological

237 heterogeneity in the patient characteristics and the outcome determination. Hence, it is possible that

238 biases like observer bias, could have existed in our results and our pooled analysis. Also, considering

239 the research question it is likely that this proposed observer bias might have been for the LMWH

240 groups as investigators expect more bleeding in this group. This ideally should have shifted the effect

241 estimate more in favor of LMWH. But our results showing null association are reassuring because even

242 in the presence of observer bias favoring LMWH our results show null association.

243 Since most studies included for the review were of poor quality, better RCTs with larger sample size,

244 better randomization protocol and reporting should be conducted. It is surprising that even though these 
3 drugs are approved by the FDA, only one of the studies were conducted in the United States [24]. In effect we are using drugs on American people based on trials conducted elsewhere. Though, the other studies did involve patients of European descent it is essential to retest this RCT with other ethnic groups in the US because the FDA approval is not specific to European Americans but for every other ethnicity.

Conclusions: From our review findings and that from Lim et al. we may infer that it may be safe to use the three FDA approved LMWH in ESRD patients, without known hypercoagulable states other than the ESRD that they suffer, receiving regular intermittent hemodialysis.

Declarations of interest: No conflict of interest declared.

Sources of support: no funding of any form was provided for the review.

\section{References:}

1) Snyder JJ, Foley RN, Collins AJ. Prevalence of CKD in the United States: a sensitivity analysis using the National Health and Nutrition Examination Survey (NHANES) 1999-2004. Am J Kidney Dis. 2009; 53(2):218-228.

2) Rao MV, Qiu Y, Wang C, Bakris G. Hypertension and CKD: Kidney Early Evaluation Program (KEEP) and National Health and Nutrition Examination Survey (NHANES), 1999-2004. Am J Kidney Dis. 2008; 51(4 Suppl 2):S30-7.

3) Flegal KM, Carroll MD, Ogden CL, Curtin LR. Prevalence and trends in obesity among US adults, 1999-2008. JAMA. 2010; 303:235-241.

4) Finkelstein EA, Fiebelkorn IC, Wang G. National medical spending attributable to overweight and obesity: how much, and who's paying? Health Aff (Millwood) 2003: Suppl Web Exclusives:W3-219W3-226.

5) Mokdad AH, Ford ES, Bowman BA, Dietz WH, Vinicor F, Bales VS. Prevalence of obesity, diabetes, and obesity- related health risk factors, 2001. JAMA. 2003;289(1):76-79.

6) KDOQI; National Kidney Foundation. KDOQI Clinical Practice Guidelines and Clinical Practice Recommendations for Anemia in Chronic Kidney Disease. Am J Kidney Dis. 2006;47(5 Suppl 3):S11145.

7) Linhardt, R.J. Gunay, N. S. Production and chemical processing of low molecular weight heparins. Sem. Thromb. Hem. 1999; 25 (3): 5-16.

8) Gould MK, Dembitzer AD, Doyle RL, Hastie TJ, Garber AM: Low-molecular-weight heparins compared with unfractionated heparin for treatment of acute deep venous thrombosis. A meta-analysis of randomized, controlled trials. Ann Intern Med 1999; 130: 800-809. 
9) Gray E, Mulloy B, Barrowcliffe TW. Heparin and low-molecular-weight-heparin. Thromb Haemost 2008; 99: 807-818.

10) Nicolaides AN. Prevention and treatment of venous thromboembolism. International Consensus Statement (ICS). Guidelines according to scientific evidence. Int Angiol. 2006;25:101-61.

11) European Pharmacopedia Commission. Pharmeuropa 1991; 3: 161-165.

12) Gerlach AT, Pickworth KK, Seth SK: Enoxaparin and bleeding complications: A review in patients with and without renal insufficiency. Pharmacotherapy 2000; 20: 771-775.

13) Spinler SA, Inverso SM, Cohen M, Goodman SG, Stringer KA, Antimann EM: Safety and efficacy of unfractionated heparin versus enoxaparin in patients who are obese and patients with severe renal impairment: Analysis from the ESSENCE and TIMI 11B studies. Am Heart J 2003;146: 33-41.

14) Lim W, Cook DJ, Crowther MA. Safety and efficacy of low molecular weight heparins for hemodialysis in patients with end-stage renal failure: a meta-analysis of randomized trials. J Am Soc Nephrol. 2004;15(12):3192-206.

15) Aggarwal A, Whitaker D A, Rimmer J M, Solomon R J, Gennari F J, Sobel B E. Attenuation of platelet reactivity by enoxaparin compared with unfractionated heparin in patients undergoing haemodialysis. Nephrol Dial Transplant. 2004;19:1559-63.

16) Borm J J, Krediet R, Sturk A, ten Cate J W. Heparin versus low molecular weight heparin K 2165 in chronic hemodialysis patients: a randomized cross-over study. Haemostasis 1986;16 Suppl 2:59-68.

17) Elisaf M S, Germanos N P, Bairaktari H T, Pappas M B, Koulouridis E I, Siamopoulos K C. Effects of conventional vs. low-molecular-weight heparin on lipid profile in hemodialysis patients. Am J Nephrol. 1997; 17:153-7.

18) Gritters M, Grooteman M P, Schoorl M, Bartels P C, Scheffer P G, Teerlink T. Citrate anticoagulation abolishes degranulation of polymorphonuclear cells and platelets and reduces oxidative stress during haemodialysis. Nephrol Dial Transplant. 2006;21:153-9.

19) Harenberg J, Haaf B, Dempfle C E, Stehle G, Heene D L. Monitoring of heparins in haemodialysis using an anti-factor-Xa-specific whole-blood clotting assay. Nephrol Dial Transplant. 1995;10:217-22.

20) Hottelart C, Achard J M, Moriniere P, Zoghbi F, Dieval J, Fournier A. Heparin-induced hyperkalemia in chronic hemodialysis patients: comparison of low molecular weight and unfractionated heparin. Artif Organs. 1998;22:614-7.

21) Lane D A, Ireland H, Flynn A, Anastassiades E, Curtis J R. Haemodialysis with low MW heparin: dosage requirements for the elimination of extracorporeal fibrin formation. Nephrol Dial Transplant. 1986;1:179-87.

22) Lord H, Jean N, Dumont M, Kassis J, Leblanc M. Comparison between tinzaparin and standard heparin for chronic hemodialysis in a Canadian center. Am J Nephrol. 2002;22:58-66.

23) Mahmood D, Grubbstrom M, Lundberg L D, Olivecrona G, Olivecrona T, Stegmayr B G. Lipoprotein lipase responds similarly to tinzaparin as to conventional heparin during hemodialysis. BMC Nephrol. 2010;11:33.

24) Naumnik B, Borawski J, Mysliwiec M. Different effects of enoxaparin and unfractionated heparin on extrinsic blood coagulation during haemodialysis: a prospective study. Nephrol Dial Transplant. 2003;18:1376-82.

25) Naumnik B, Borawski J, Pawlak K, Mysliwiec M. Enoxaparin but not unfractionated heparin causes a dose-dependent increase in plasma TGF-beta 1 during haemodialysis: a cross-over study. Nephrol Dial Transplant. 2007;22:1690-6.

26) Naumnik B, Pawlak K, Mysliwiec M. Different effect of unfractionated heparin and enoxaparin on circulating proangiogenic factors during hemodialysis: A cross-over study. Cytokine. 2007;40:98-104.

27) Naumnik B, Pawlak K, Mysliwiec M. Different effects of enoxaparin and unfractionated heparin on some thrombogenesis markers during hemodialysis: a cross-over study. Thromb Res. 2009;123:631-6. 
28) Naumnik B, Pawlak K, Mys'liwiec M. Unfractionated heparin but not enoxaparin causes delayed plasma PAI-1 depletion in hemodialysis patients: a prospective study. Clin Appl Thromb Hemost. 2009;15:8491.

29) Poyrazoglu O K, Dogukan A, Yalniz M, Seckin D, Gunal A L. Acute effect of standard heparin versus low molecular weight heparin on oxidative stress and inflammation in hemodialysis patients. Ren Fail. 2006;28:723-727.

30) Ryan K E, Flynn A, Shepperd J, Ireland H, Lane D A, Curtis J R. Dose-finding study of a low molecular weight heparin (LMWH), Innohep, in haemodialysis [abstract: P55]. 1990;23.

31) Saltissi D, Morgan C, Westhuyzen J, Healy H. Comparison of low-molecular-weight heparin (enoxaparin sodium) and standard unfractionated heparin for haemodialysis anticoagulation. Nephrol Dial Transplant. 1999;14:2698-703.

32) Schrader J, Stibbe W, Armstrong V W, Kandt M, Muche R, Kostering H. Comparison of low molecular weight heparin to standard heparin in hemodialysis/hemofiltration. Kidney Int. 1988;33:890-6.

33) Verzan C, Capsa D, Covic A, Mota E, Verzan M, Barbulescu C. Comparison between tinzaparin and standard heparin for chronic hemodialysis [abstract]. 2004; 175.

34) Janssen MJ, Deegens JK, Kapinga TH, Beukhof JR, Huijgens PC, van Loenen AC, van der MJ: Citrate compared to low molecular weight heparin anticoagulation in chronic hemodialysis patients. Kidney Int 1996;49: 806-813.

35) Reach I, Luong N, Chastang C, Chakroun M, Mirshahi S, Mirshahi MC, Soria J, Desmichels D, Baumelou A: Dose effect relationship of reviparin in chronic hemodialysis: A crossover study versus nadroparin. Artif Organs 2001. 25: 591-595.

36) Stefoni S, Cianciolo G, Donati G, Coli L, La Manna G, Raimondi C, Dalmastri V, Orlandi V, D’Addio F: Standard heparin versus low-molecular-weight heparin. A medium-term comparison in hemodialysis. Nephron 2002; 92: 589-600.

37) Nurmohamed MT, ten Cate J, Stevens P, Hoek JA, Lins RL, ten Cate JW: Long-term efficacy and safety of a low molecular weight heparin in chronic hemodialysis patients. A comparison with standard heparin. ASAIO Trans 1991; 37: M459-M461.

38) Liu ZQ, Wang L: Comparison of anticoagulation efficacy and clinical safety between imported and domestically manufactured low-molecular-weight heparin during hemodialysis. Di Yi Junyi Daxue Xuebao 2002; 22: 942-943.

39) Apsner R, Buchmayer H, Lang T, Unver B, Speiser W, Sunder-Plassmann G, Horl WH: Simplified citrate anticoagulation for high-flux hemodialysis. Am J Kidney Dis 2001; 38: 979-987.

40) Polkinghorne KR, McMahon LP, Becker GJ: Pharmacokinetic studies of dalteparin (Fragmin), enoxaparin (Clexane), and danaparoid sodium (Orgaran) in stable chronic hemodialysis patients. Am J Kidney Dis 2002; 40: 990-995.

41) Beijering RJR, ten Cate H, Stevens P, Vanholder R, Van Dorp WT, Van Olden RW, Wickstrom B, Sprogel P, ten Cate JW: Randomised long-term comparison of tinzaparin and dalteparin in haemodialysis. Clin Drug Invest 2003; 3: 85-97.

42) Anastassiades E, Ireland H, Flynn A, Lane DA, Curtis JR: A low-molecular-weight heparin (kabi 2165, "fragmin") in repeated use for haemodialysis: Prevention of clotting and prolongation of the venous compression time in comparison with commercial unfractionated heparin. Nephrol Dial Transplant 1990; 5: 135- 140 .

43) Anastassiades E, Lane DA, Ireland H, Flynn A, Curtis JR: A low molecular weight heparin ("fragmin") for routine hemodialysis: A crossover trial comparing three dose regimens with a standard regimen of commercial unfractionated heparin. Clin Nephrol 1989; 32: 290-296.

44) van Veen JJ, Maclean RM, Hampton KK, Laidlaw S, Kitchen S, Toth P, Makris M. Protamine reversal of low molecular weight heparin: clinically effective? Blood Coagul Fibrinolysis. 2011;22(7):565-70. 


\section{Table $\mathbf{1}$ (on next page)}

Characteristics of included studies

Table details the characteristics of the studies included in the review 


\begin{tabular}{|c|c|c|c|c|c|c|c|c|c|c|}
\hline $\begin{array}{c}\text { Name of first } \\
\text { Author }\end{array}$ & Aggarwal & Borm & Elisaf & Gritters & $\begin{array}{c}\text { Harenber } \\
\text { g }\end{array}$ & Hottelart & Lane & Lord & Verzan & Naumnik \\
\hline Year & 2004 & 1986 & 1997 & 2006 & 1995 & 1998 & 1986 & 2002 & 2004 & 2009 \\
\hline Methods & Parallel RCT & Crossover RCT & $\begin{array}{l}\text { Crossover } \\
\text { RCT }\end{array}$ & Crossover RCT & $\begin{array}{c}\text { Parallel } \\
\text { RCT }\end{array}$ & Crossover RCT & Crossover RCT & Crossover RCT & Crossover RCT & Parallel RCT \\
\hline Participants & 20 & 10 & 36 & 8 & 20 & 11 & 8 & 32 & 66 & 22 \\
\hline Interventions & Enoxaparin & Dalteparin & Tinzaparin & Dalteparin & Dalteparin & $\begin{array}{l}\text { LMWH not } \\
\text { specified }\end{array}$ & Dalteparin & Tinzaparin & Tinzaparin & Enoxaparin \\
\hline $\begin{array}{c}\text { Dose } \\
\text { (fixed/variable) }\end{array}$ & Fixed & Fixed & Variable & Fixed & Fixed & Variable & Fixed & Variable & Variable & Fixed \\
\hline Country & United States & Netherlands & Greece & Netherlands & Germany & France & United Kingdom & Canada & Romania & Poland \\
\hline Notes & & & & & & & $\begin{array}{l}\text { Difficult to assess } \\
\text { randomization } \\
\text { groups for } \\
\text { outcomes } \\
\end{array}$ & & $\begin{array}{c}\text { Abstract- specific } \\
\text { data not provided } \\
\text { for circuit } \\
\text { thrombosis } \\
\end{array}$ & \\
\hline Outcomes & $\begin{array}{l}\text { ADP-induced } \\
\text { fibrinogen } \\
\text { binding, } \\
\text { platelet } \\
\text { reactivity }\end{array}$ & $\begin{array}{c}\text { Extracorporeal } \\
\text { circuit } \\
\text { thrombosis, } \\
\text { bleeding } \\
\text { complications, } \\
\text { factor Xa levels, } \\
\text { platelet } \\
\text { function, beta- } \\
\text { thromboglobulin, } \\
\text { thromboxane } \\
\text { A2, platelet } \\
\text { factor } 4, \\
\text { serotonin }\end{array}$ & $\begin{array}{c}\text { Lipid profile } \\
\text { (HDL, LDL, } \\
\text { total } \\
\text { cholesterol, } \\
\text { apo A1,apo } \\
\text { B, } \\
\text { triglycerides, } \\
\text { lipoprotein } \\
\text { a), albumin, } \\
\text { hemoglobin }\end{array}$ & $\begin{array}{l}\text { Platelet factor } 4, \\
\text { polymorphonuclear } \\
\text { cells and platelet } \\
\text { degranulation }\end{array}$ & $\begin{array}{l}\text { Hep test, } \\
\text { aPTT, } \\
\text { thrombin } \\
\text { clotting } \\
\text { time }\end{array}$ & $\begin{array}{c}\text { Plasma } \\
\text { aldosterone, renin, } \\
\text { aldosterone/renin } \\
\text { ratio, serum } \\
\text { potassium }\end{array}$ & $\begin{array}{c}\text { Fibrinopeptide A, } \\
\text { beta- } \\
\text { thromboglobulin, } \\
\text { kaolin cephalin } \\
\text { clotting time, } \\
\text { plasma heparin } \\
\text { levels, bleeding } \\
\text { time }\end{array}$ & $\begin{array}{c}\text { Extracorporeal } \\
\text { circuit thrombosis, } \\
\text { bleeding } \\
\text { complications, } \\
\text { vascular } \\
\text { compression time, } \\
\text { patient/nurse } \\
\text { satisfaction, } \\
\text { relative cost, } \\
\text { nursing time }\end{array}$ & $\begin{array}{c}\text { Extracorporeal } \\
\text { circuit thrombosis }\end{array}$ & $\begin{array}{l}\text { Thrombomodulin, } \\
\text { von-Willebrand } \\
\text { factor, plasminogen } \\
\text { activator inhibitor 1, } \\
\text { cell surface } \\
\text { adhesion molecule, } \\
\text { e-selectin, } \\
\text { intercellular } \\
\text { adhesion molecule } \\
1 \text {, prothrombin } \\
\text { fragment } 1+2\end{array}$ \\
\hline $\begin{array}{c}\text { Name of first } \\
\text { Author }\end{array}$ & Mahmood & Naumnik & Naumnik & Naumnik & Naumnik & Poyrazoglu & Ryan & Saltissi & Schrader & \\
\hline Year & 2010 & 2003 & 2007 & 2007 & 2009 & 2006 & 1990 & 1999 & 1988 & \\
\hline Methods & $\begin{array}{l}\text { Crossover } \\
\text { RCT }\end{array}$ & Parallel RCT & $\begin{array}{l}\text { Crossover } \\
\text { RCT }\end{array}$ & Crossover RCT & $\begin{array}{c}\text { Crossover } \\
\text { RCT }\end{array}$ & Parallel RCT & Crossover RCT & Crossover RCT & Parallel RCT & \\
\hline Participants & 20 & 25 & 22 & 22 & 22 & 33 & 8 & 36 & 70 & \\
\hline Interventions & Tinzaparin & Enoxaparin & Enoxaparin & Enoxaparin & $\begin{array}{c}\text { Enoxapari } \\
\mathrm{n}\end{array}$ & Dalteparin & Tinzaparin & Enoxaparin & Dalteparin & \\
\hline $\begin{array}{c}\text { Dose } \\
\text { (fixed/variable) }\end{array}$ & Fixed & Fixed & Fixed & Fixed & Fixed & Fixed & Fixed & Variable & Variable & \\
\hline Country & Sweden & Poland & Poland & Poland & Poland & Turkey & United Kingdom & Australia & Germany & \\
\hline Notes & & & & & & & Abstract & & & \\
\hline
\end{tabular}




\begin{tabular}{|c|c|c|c|c|c|c|c|c|c|}
\hline Outcomes & $\begin{array}{c}\text { Lipid profile } \\
\text { (LDL, HDL, } \\
\text { total } \\
\text { cholesterol, } \\
\text { triglycerides) } \\
\text { and } \\
\text { lipoprotein } \\
\text { lipase }\end{array}$ & $\begin{array}{l}\text { Pro-thrombotic } \\
\text { tissue factor, } \\
\text { tissue factor } \\
\text { pathway } \\
\text { inhibitor, } \\
\text { activated } \\
\text { coagulation } \\
\text { marker } \\
\text { prothrombin } \\
\text { fragment } 1+2\end{array}$ & $\begin{array}{l}\text { Transformin } \\
\text { g growth } \\
\text { factor beta-1, } \\
\text { platelet } \\
\text { derived } \\
\text { growth factor } \\
\text { AB, beta- } \\
\text { thromboglob } \\
\text { ulin, platelet } \\
\text { factor } 4\end{array}$ & $\begin{array}{l}\text { Vascular endothelial } \\
\text { growth factor, basic } \\
\text { fibroblast growth } \\
\text { factor }\end{array}$ & $\begin{array}{c}\text { Prothrombi } \\
\text { n } \\
\text { fragment1 } \\
+2, \\
\text { thrombin/a } \\
\text { nti- } \\
\text { thrombin } \\
\text { complex }\end{array}$ & $\begin{array}{l}\text { C-reactive protein, } \\
\text { tumor necrosis } \\
\text { factor alpha, } \\
\text { superoxide } \\
\text { dismutase, } \\
\text { malondialdehyde }\end{array}$ & $\begin{array}{c}\text { Anti-factor Xa } \\
\text { activity, } \\
\text { fibrinopeptide A, } \\
\text { beta- } \\
\text { thromboglobulin, } \\
\text { hep test }\end{array}$ & $\begin{array}{c}\text { Extracorporeal } \\
\text { circuit thrombosis, } \\
\text { bleeding } \\
\text { complications, } \\
\text { vascular } \\
\text { compression time, } \\
\text { lipid profile (LDL, } \\
\text { HDL, VLDL, } \\
\text { triglycerides, } \\
\text { cholesterol) }\end{array}$ & $\begin{array}{c}\text { Extracorporeal } \\
\text { circuit thrombosis, } \\
\text { bleeding } \\
\text { complications, lipid } \\
\text { profile, factor Xa } \\
\text { level, erythrocyte } \\
\text { concentration }\end{array}$ \\
\hline
\end{tabular}

\section{Table 1: Characteristics of Included Studies}


Table 2 (on next page)

Patient characteristics (patients in studies that reported outcomes of interest)

Characteristics of patients in the included studies 


\section{Table 2: Patient characteristics (patients in studies that reported outcomes of interest)}

\begin{tabular}{|c|c|c|c|c|c|c|c|c|c|c|}
\hline \multirow{2}{*}{$\begin{array}{l}\text { Study, Year } \\
\text { (reference) }\end{array}$} & \multirow{2}{*}{$\begin{array}{l}\text { Mean age } \\
(\mathrm{yrs}) \pm \mathrm{SD}\end{array}$} & \multicolumn{2}{|c|}{ Excluded patients } & \multirow{2}{*}{$\begin{array}{l}\text { Follow-up } \\
\text { duration }\end{array}$} & \multirow{2}{*}{$\begin{array}{l}\text { Patients } \\
\text { lost to } \\
\text { follow-up }\end{array}$} & \multirow{2}{*}{$\begin{array}{l}\text { Patients (n): } \\
\text { LMWH/UH }\end{array}$} & \multirow{2}{*}{$\begin{array}{l}\text { Frequency } \\
\text { and duration } \\
\text { of dialysis }\end{array}$} & \multirow{2}{*}{$\begin{array}{l}\text { Type of } \\
\text { LMWH }\end{array}$} & \multirow{2}{*}{$\begin{array}{l}\text { Mean } \\
\text { LMWH } \\
\text { dose }\end{array}$} & \multirow[t]{2}{*}{ Mean UFH dose } \\
\hline & & $\begin{array}{l}\text { Other } \\
\text { anticoagulants }\end{array}$ & $\begin{array}{l}\text { Previous } \\
\text { bleeding }\end{array}$ & & & & & & & \\
\hline Borm, 1986 & 58.6 & No & NS & NS & $0 / 0$ & 10 & 2-3/wk, 4hrs & Dalteparin & $\begin{array}{l}\text { (B) } 18 \\
\text { IU/kg; (I) } 9 \\
\text { IU/Kg/hr }\end{array}$ & $\begin{array}{l}\text { (B) } 36 \mathrm{IU} / \mathrm{kg} \text {; (I) } \\
18 \mathrm{IU} / \mathrm{Kg} / \mathrm{hr}\end{array}$ \\
\hline Saltissi, 1999 & 68.5 & No & No & 24 weeks & 5 & 36 & $\begin{array}{l}3-4 / \text { wk, 3-5 } \\
\text { hours }\end{array}$ & Enoxaparin & $\begin{array}{l}(\mathrm{B}) \\
1 \mathrm{mg} / \mathrm{kg} ;(\mathrm{I}) \\
0.69 \\
\mathrm{mg} / \mathrm{Kg} / \mathrm{hr}\end{array}$ & $\begin{array}{l}\text { (B) } 50 \mathrm{IU} / \mathrm{kg} \text {; (I) } \\
1000 \mathrm{IU} / \mathrm{hr}\end{array}$ \\
\hline Lord, 2002 & $66.6 \pm 14.8$ & No & No & 8 weeks & 2 & 32 & $\begin{array}{l}3 / \text { wk, } 3.5-4 \\
\text { hours }\end{array}$ & Tinzaparin & $4318 \mathrm{IU}$ & $\begin{array}{l}\text { (B) } 50-75 \\
\text { IU/Kg; (I) NS }\end{array}$ \\
\hline $\begin{array}{l}\text { Schrader, } \\
1988\end{array}$ & $\begin{array}{l}54 \pm 15.2 \\
(\mathrm{LMWH}), \\
51.6 \pm 17.9 \\
(\mathrm{UFH})\end{array}$ & No & NS & 12 months & 8 & $70(35 / 35)$ & $\begin{array}{l}\text { NS, } 4.5-5 \\
\text { hours }\end{array}$ & Dalteparin & $\begin{array}{l}\text { (B) } 34 \\
\text { IU/kg; (I) } \\
12 \\
\text { IU/Kg/hr }\end{array}$ & $\begin{array}{l}\text { (B) } 62 \mathrm{IU} / \mathrm{Kg} \text {; (I) } \\
17 \mathrm{IU} / \mathrm{kg}\end{array}$ \\
\hline $\begin{array}{l}\text { Harenberg } \\
1995\end{array}$ & $\begin{array}{l}53.4 \pm 19.9 \\
(\mathrm{LMWH}), \\
59.1 \pm \\
15.72 \\
(\mathrm{UFH})\end{array}$ & NS & NS & NS & NS & $20(10 / 10)$ & $\begin{array}{l}3-4 \text { hours, } \\
4 / \mathrm{wk}\end{array}$ & Dalteparin & $\begin{array}{l}\text { (B) } 1750 \\
\text { IU (I) } 26.4 \\
\text { IU/Kg }\end{array}$ & $\begin{array}{l}\text { (B) } 2650 \mathrm{IU} ; 36.6 \\
\text { IU infusion }\end{array}$ \\
\hline Verzan 2004 & NS & NS & NS & NS & NS & 66 & $\begin{array}{l}\text { 3/wk, 4-5 } \\
\text { hrs/session }\end{array}$ & Tinzaparin & $40 \mathrm{IU} / \mathrm{kg}$ & $\begin{array}{l}\text { mean dose } 6262 \\
2300 I U / \text { session }\end{array}$ \\
\hline $\begin{array}{l}\text { Mahmood } \\
2010\end{array}$ & $52.1 \pm 17.2$ & NS & NS & NS & NS & 20 & $\begin{array}{l}\text { 3/wk, 4-5 } \\
\text { hrs/session }\end{array}$ & Tinzaparin & $\begin{array}{l}\text { (B) } 34 \\
\text { IU/kg; (I) } \\
12 \\
\text { IU/Kg/hr }\end{array}$ & $\begin{array}{l}\text { (B) } 62 \mathrm{IU} / \mathrm{Kg} \text {; (I) } \\
17 \mathrm{IU} / \mathrm{kg}\end{array}$ \\
\hline Gritters 2006 & $55.2 \pm 11.7$ & NS & NS & NS & NS & 8 & $\begin{array}{l}\text { 3/wk, 4-5 } \\
\text { hrs/session }\end{array}$ & Dalteparin & NS & $\begin{array}{l}\text { (B) } 62 \mathrm{IU} / \mathrm{Kg} \text {; (I) } \\
17 \mathrm{IU} / \mathrm{kg}\end{array}$ \\
\hline Elisaf 1997 & $57.1 \pm 12.3$ & NS & NS & NS & NS & 36 & $\mathrm{NS}$ & Tinzaparin & $\begin{array}{l}\text { (B) } 34 \\
\text { IU/kg; (I) } \\
12 \\
\text { IU/Kg/hr }\end{array}$ & $\mathrm{NS}$ \\
\hline
\end{tabular}

3 NS: Not Specified 
Table 3 (on next page)

Summary table for meta-analysis (extracorporeal circuit thrombosis)

Table detailing the event rates of comparison between LMWH and UH for extracorporeal circuit thrombosis 
2 Table 3: Summary table for meta-analysis (extracorporeal circuit thrombosis)

\begin{tabular}{|l|l|l|l|l|l|l|}
\hline \multirow{2}{*}{ Study } & \multicolumn{2}{|l|}{ LMWH } & UFH & $\begin{array}{l}\text { Risk } \\
\text { ratio }\end{array}$ & 95\% CI \\
\cline { 2 - 6 } & Events & $\begin{array}{l}\text { No. of HD } \\
\text { sessions }\end{array}$ & Events & $\begin{array}{l}\text { No. of HD } \\
\text { sessions }\end{array}$ & & \\
\hline Borm 1986 & 4 & 10 & 4 & 10 & 1.00 & $0.34-2.93$ \\
\hline Schrader 1988 & 80 & 5045 & 69 & 5197 & 1.19 & $0.87-1.64$ \\
\hline Saltissi 1999 & 17 & 1111 & 35 & 1141 & 0.50 & $0.28-0.89$ \\
\hline Lord 2002 & 32 & 378 & 21 & 382 & 1.54 & $0.90-2.62$ \\
\hline Total & 133 & 6544 & 129 & 6730 & 1.00 & $0.62-1.62$ \\
\hline
\end{tabular}

3 


\section{Table 4 (on next page)}

Summary table for meta-analysis (Bleeding complications)

Table details the event rates comparison between LMWH and UH for Bleeding Complications 
2 Table 4: Summary table for meta-analysis (Bleeding complication)

\begin{tabular}{|l|l|l|l|l|l|l|}
\hline \multirow{2}{*}{ Study } & LMWH & UFH & $\begin{array}{l}\text { Risk } \\
\text { ratio }\end{array}$ & $95 \%$ CI \\
\cline { 2 - 7 } & Events & No. of Patients & Events & No. of patients & \\
\hline Borm 1986 & 2 & 10 & 1 & 10 & 2.00 & $0.21-18.69$ \\
\hline Schrader 1988 & 19 & 35 & 16 & 35 & 1.19 & $0.74-1.90$ \\
\hline Saltissi 1999 & 12 & 36 & 6 & 36 & 2.00 & $0.84-4.75$ \\
\hline Lord 2002 & 3 & 32 & 8 & 32 & 0.38 & $0.11-1.29$ \\
\hline Total & 36 & 113 & 31 & 113 & 1.16 & $0.62-2.15$ \\
\hline
\end{tabular}

3 
1

Article Flow Diagram

Details the process of study inclusion into the review

4095 citations identified

by searching Medline, Embase and Cochrane central

735 records after removing duplicates

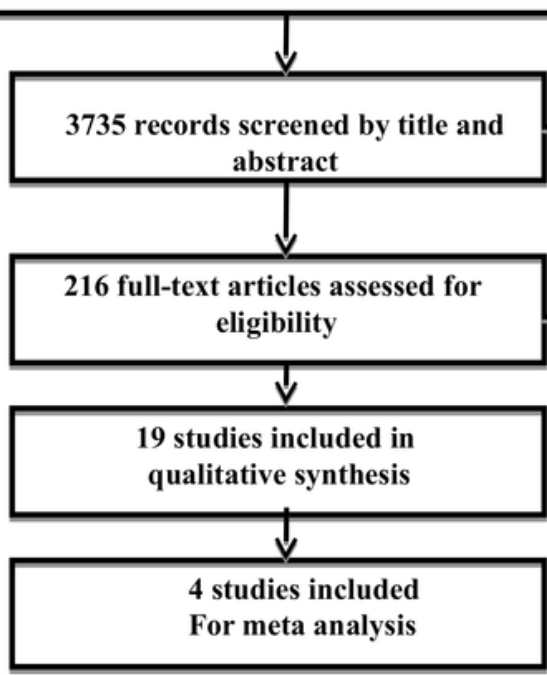

3519 records excluded

Full text articles excluded:

1.Not retrievable: 25

2.Language not understandable: 5

3. Not RCT: 72

4. Not LMWH Vs UH: 88.

5.2 pediatric only studies

6.3 duplicates

7.2 non outpatient hemodialysis 
2

Forest Plots: Extracorporeal Circuit Thrombosis

Forest Plots comparing LMWH Vs UH for extracorporeal Circuit Thrombosis

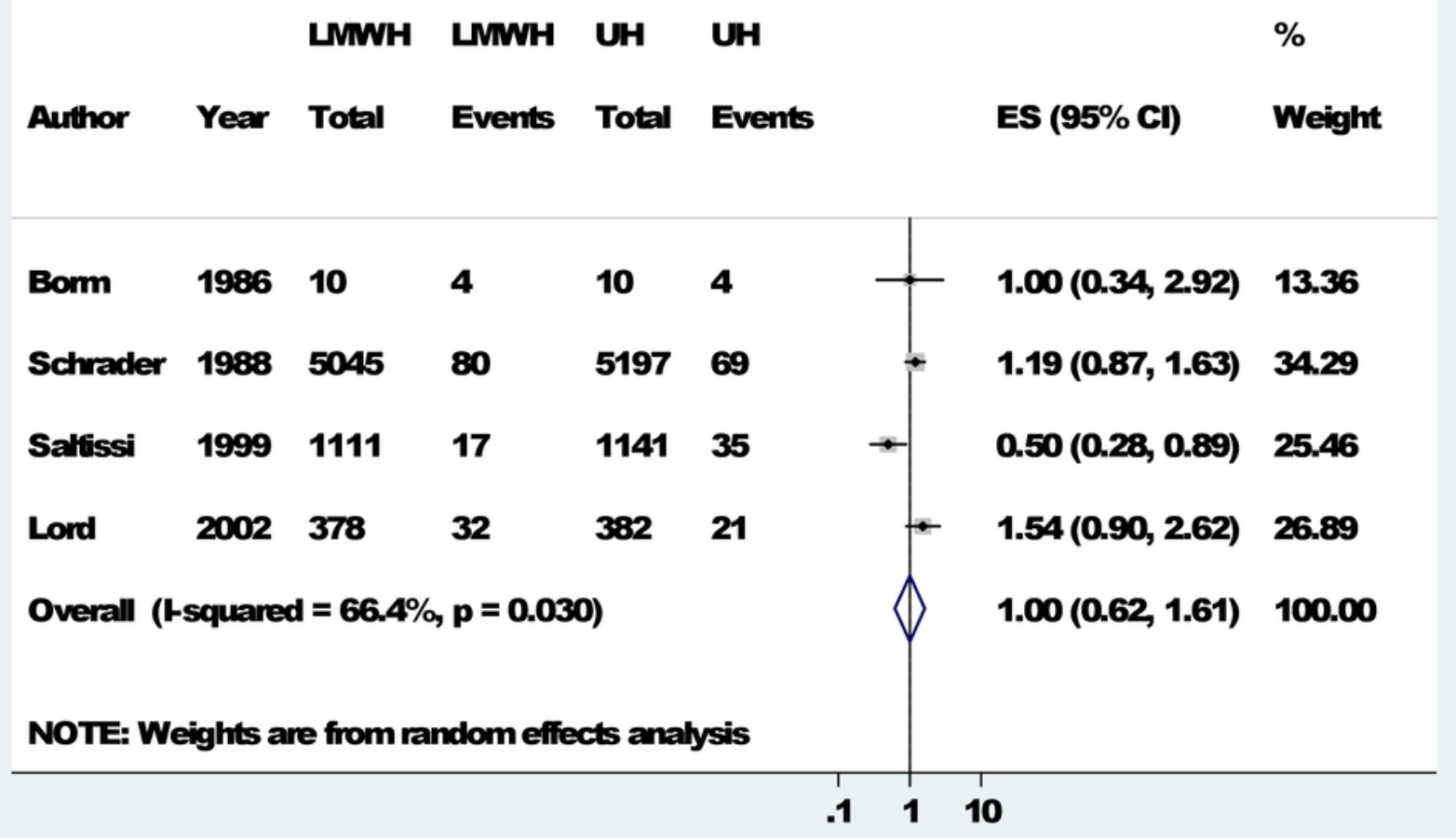




\section{3}

Forest Plots: Bleeding Complications

Forest Plots comparing LMWH Vs UH for Bleeding Complications

LMWH LMWH UH UH $\%$

Author Year Total Events Total Events ES (95\% Cl) Weight

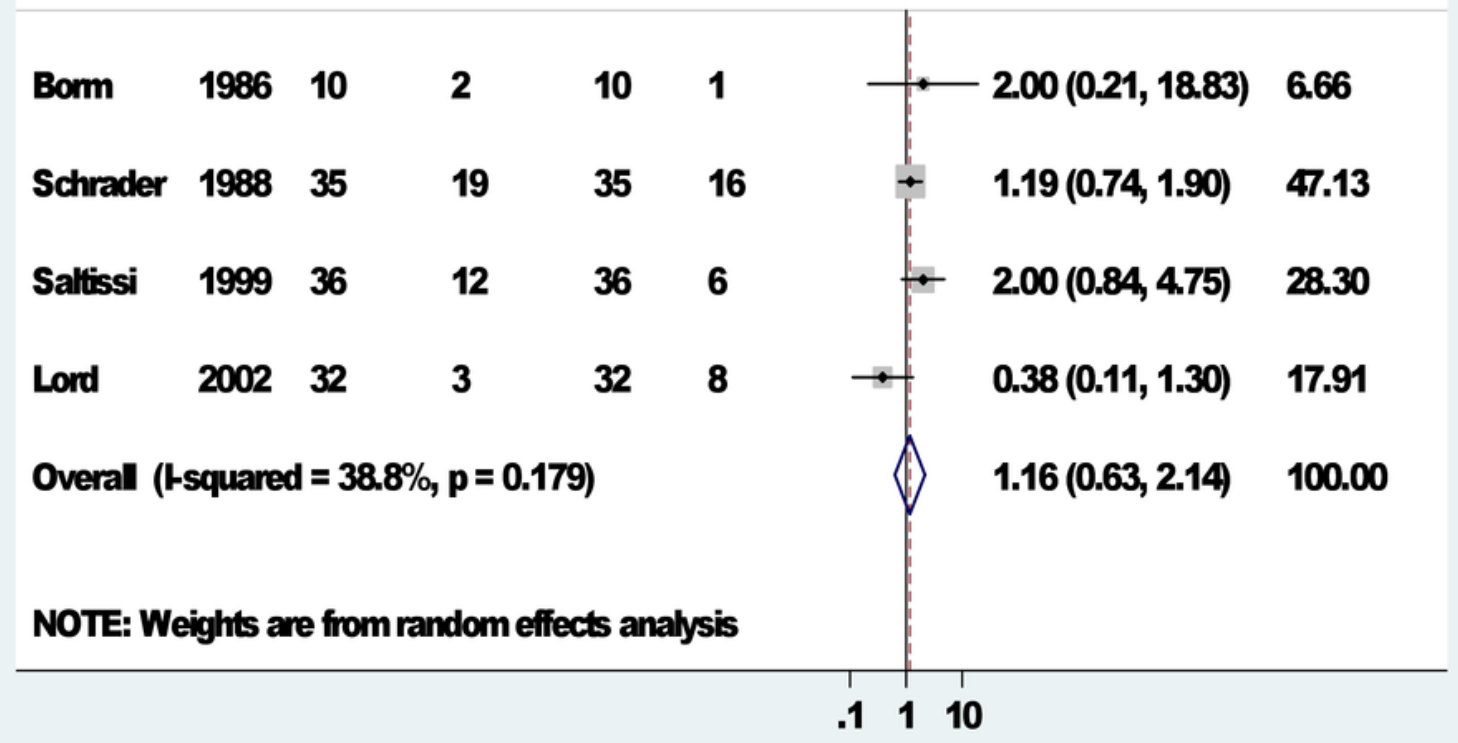

